Margaret Y. K. Woo / Mary E. Gallagher (eds),

\title{
Chinese Justice. Civil Dispute Resolution in Contemporary China
}

Cambridge: Cambridge University Press, 2011, xxiii 407 pp, hardback, ISBN 978-1-107-00624-9

In the years after the establishment of the People's Republic of China (PRC) in 1949, most law on the Chinese mainland came to follow Soviet models. Later, the increasingly ideologised politics of Mao Zedong pushed law, on the books and in people's lives, progressively off the stage, culminating in the chaos and frenzy of the "Great Proletarian Cultural Revolution". After the demise of the Great Helmsman and the ouster of his satraps, styled the "Gang of Four", the ominous whimsicality of the "rule of men" (renzhi) was determinedly discarded in favour of more law-based governance (fazhi).

This new course also suited the requirements of the government's development strategy which emphasised the massive attraction of foreign investment and international economic co-operation and trade. Domestic economic reform in turn generated growing numbers of actors no longer closely guided by central directives and who would thus need general norms to govern their behaviour in a nascent marketplace. As a result, PRC legislation during the decades of "Reform and Opening" since 1978 has produced a large body of laws, accompanied by a resumption of academic legal scholarship and the renewed emergence of jurists, in the revived judicial institutions and the legal profession.

The multiplicity of actors in the marketplace and of individual choices in the private lives of Chinese citizens nevertheless remains enveloped in a political dispensation marked by one-party rule. This dichotomy, of continued socio-economic diversification and a unicoloured body politic permeates evolving law-based governance (fazhi) in the PRC.

Much of this dichotomy is not readily visible in laws on the books. The volume under review has therefore very aptly chosen to inspect Chinese justice from the bottom up, and from a variety of methodological angles, helpfully relying on numerous interviews with practitioners and users of law and legal processes. The book divides into three parts: Legal Development and Institutional Tensions, Dissemination of the Law in the Chinese Context, and Law from the Bottom Up.

The enquiries into the development of legal institutions and the influence on them by social conditions both before 1949 and during the Mao era of the PRC reveal rich seams of heritage informing present-day structures. The interplay of personnel administration and its system of rewards and sanctions in regard to judges and the meandering policies on the use of mediation rather that adjudication illustrate the variety of political forces tugging at law and legal procedures. A detailed survey of slowly expanding inclusion of constitutional considerations in juridical argument traces the floating wisps of a fluid legal dance of as yet uncertain direction by which citizens' rights enshrined in the PRC constition are being instilled into concrete legal relationships. The legal - and political - dynamics of China's "Reform and Opening" era are vividly brought to life in the papers assembled in this book. 
Readers wishing to appreciate the practical import of law in contemporary China beyond the norms on paper will benefit from this work.

The internet has now turned into the one, huge, sphere in the PRC that allows rumbustious debate to a netizen population of by now over 485 million. As a barometer of public opinion it has also frequently served as a conduit of discontent at court decisions or administrative action. It is perhaps due to the methodological constraints of the surveys contained in this book that the internet and its effects on the law have not been discussed in this collection. The Chinese-English glossary includes numerous terms of a general character and also occasional mistranslations (eg, sifa wei min as "legality serving the people": sifa meaning not 'legality' but 'justice', as in 'Justice Department'). One minor blunder mars the edition of this very informative publication: The two Chinese characters on the front cover of the book simply say 'Zhongguo' (China), not 'Justice' as stated on the back cover.

Wolfgang Kessler, Canton

\section{Heinrich Scholler}

\section{Rechtsreform und Rechtstransfer in der Mongolei}

LIT Verlag, Berlin, 2010, 197 S., € 19,90; ISBN 978-3-643-10747-3

Als Band 1 einer von ihm herausgegebenen neuen Reihe „Recht und Politik in Asien“ legt Heinrich Scholler eine Art Zwischenbilanz seiner Beschäftigung mit und seiner Tätigkeit in der Mongolei vor, gewidmet seinen „Doktorandinnen und Doktoranden aus der Mongolei“; solche Zuwendung und Zuneigung lassen auch die Texte erspüren.

Die Mongolei, das am dünnsten besiedelte Land der Erde, zugleich (nach Kasachstan) der zweitgrößte Binnenstaat, erfuhr ihre Wende und Hinwendung zu rechtsstaatlichen Strukturen und begann ihren Weg zur Demokratie im Jahre 1992 - , mit der Erringung der Unabhängigkeit“, wie Scholler im Vorwort schreibt; als eine materiell gemeinte Feststellung ist das zutreffend. Schon früh nach dem Beginn der Neuorientierung in dem sich noch heute stolz auf Dschingis Khan besinnenden, vielfältig im Laufe der Geschichte mit dem großmächtigen südlichen Nachbarn China (der Enkel des Dschingis begründete dort im 13. Jahrhundert mit der Dynastie Yuan kaiserliche Herrschaft) verflochtenen Staatswesen, das 1924 zum zweiten kommunistischen Staat der Welt geworden war und in vielem an die Seite des Sowjetunion getreten, war Heinrich Scholler in der Mongolei beratend, informierend und mitgestaltend tätig beim Umbau und Aufbau neuen Rechts und hierauf bezogener Institutionen. Den Inhalt des vorliegenden Bandes bilden im wesentlichen Vortragsmanuskripte und Berichte aus jener Zeit, eine, wie Scholler schreibt, ,,sozusagen überarbeitete zweite Auflage“ einer Publikation der Hanns Seidel Stiftung zu „Rechts- und Verwaltungsreform in der Mongolei“" von 2001, aktualisiert wo nötig und geboten. In sechs Abschnitten werden rechtshistorische Ausgangspunkte bezeichnet (mit bemerkenswerten Ausführungen zu der Frage, ob es eine „mongolische Rechtsfamilie“ i.S. eines eigenständigen Rechtskrei- 